\title{
The perception of participation in executive governance structures in Dutch universities
}

Paper presented at the Annual EAIR Forum

Riga, Latvia, 28-31 August, 2005

- Not to be quoted without the permission of the authors -

Jeroen Huisman

International Centre for Higher Education Management

University of Bath (UK)

j.huisman@bath.ac.uk

Harry de Boer

Center for Higher Education Policy Studies

University of Twente (NL)

h.f.deboer@utwente.nl

Leo Goedegebuure

University of New England (AUS)

lgoedege@une.edu.au 


\section{Background}

The enhancement of institutional autonomy has been one of the central objectives in the policies of the Dutch government since 1985. In this perspective the establishment of stronger executive leadership has been regarded as necessary. In 1997, the Dutch parliament accepted a new bill on university governance (Modernisation of University Governance, Dutch acronym: MUB). Besides increasing the university's autonomy the objectives of the change in governance were integrated management, transparency in internal authority relationships, 'full' participation of the members of the university community, and effective and efficient decision-making. This MUB Act abolished the system of codetermination by executive board and representative council. At the central university level nearly all powers regarding academic and non-academic affairs were attributed to the Central Executive Board (College van Bestuur). This executive board became accountable to a new body, the Supervisory Board, whose members are appointed by and accountable to the Minister. The Supervisory Board appoints the three members of the Central Executive Board, which consists of three persons. One of these, the rector, should be selected from the professors of the university, the other two members may be drawn from outside the institution (usually these two board members are not academics). In its turn, the Central Executive Board appoints the dean(s), who may be drawn from inside or outside the university. At the faculty level, the deanship has become the most powerful position. At both university and faculty levels, the representative councils (consisting of staff and students) were retained, but the councils lost some of their earlier powers. On paper the nature of their role has been changed from co-decision into mainly advising (De Boer and Goedegebuure, 2001). However, compared to pure advisory bodies they have still some additional authorities (such as the right to agree on the university's strategic plan, i.e. without agreement of the representative council such a plan cannot be put into action).

The MUB Act clearly underlines the government's rationale to stress economy, efficiency and effectiveness as leading values in the governance and management of public organisations. In the Explanatory Memorandum of the MUB the minister argued that universities operating in an environment of scarcity and competition are to a large extent irreconcilable with democratic and participatory modes of governance (e.g. representative leadership in which staff (and students) are the sovereign powers in the university). As the general argument goes, universities nowadays need to respond quickly, sometimes have to take hard decisions and this requires strong, risktaking executive leadership. As such, the basic ideas of the new governance act can easily be traced back to the principles of New Public Management (Pollitt, 1990; Clarke and Newman, 1997; Pollitt and Bouckaert, 2000).

It should be stressed that the Dutch policy initiatives are not unique in the European context. Many other European higher education systems show signs of developments towards New Public Management (see e.g. Neave and Van Vught, 1991; Amaral et al., 2002). But whereas the narrative of New Public Management may be strong, it is a different question whether the features are implemented as intended and how they are perceived and felt by those inside higher education institutions. We believe that achievement is in the eye of the beholder. Therefore we are particularly interested in the views and perspectives of actors - both the executives and council members (which we will term 'governors' in this paper) and 'regular' (in the sense of not being active in governing bodies) academics, students and support staff (which we will term the 'governed'). This paper particularly focuses on one of the objectives of the 1997 governance reform, the realisation of 'full' participation. To assess the government's objective of full participation within an executive-dominated structure we portray perceptions and views of 
governors and governed with respect to some cardinal participation issues. These perceptions and views are obtained through a national evaluation that has been conducted in 2005 .

The design of the national evaluation study on the university governance structure

In 1998, the Committee Datema (1998) monitored the implementation of the MUB Act.

Its final report detailed the choices made by the respective universities and portrayed the then current governance structures. In 2001, the minister compelled the universities to evaluate their governance structure themselves (Van den Berg et al. 2001). On the basis of the self-evaluations the minister reported that several objectives of the MUB Act were obtained, or that the universities were at least on the right track. Though opinions differed on the accuracy and correctness of the self-evaluations, there was a generally supported conclusion that the objective of 'full participation' was absolutely not met (see e.g. LSVb 2002, De Boer and Goedegebuure 2002). And after some years a new, more comprehensive evaluation study was asked for. The national evaluation study in 2005 was commissioned by the Dutch Ministry of Education, Culture and Science and carried out by the University of Twente's Center for Higher Education Policy Studies (CHEPS). It aimed to fully cover the impact of the new governance structure on its community members. It focused first on the actual choices that universities made regarding the formal objectives of the governance act: integrated management, transparent accountability relationships, 'full' student and staff participation in decision-making, and the institutional leeway to adjust governance structures to local preferences. Secondly, it addressed the actual appraisal of nearly all the different actors within the universities (leaders, managers, staff, and students) of the governance structure. Third, it formulated conclusions and suggestions to improve (when necessary) the current governance situation.

The first part of the research is based on analyses of university documents and some interviews with those knowledgeable on the developments in the particular universities (members of the Central Executive Board, secretaries to these boards, etc.). The second part of the research is based on a large-scale survey among various key persons within the governance structure. Questionnaires have been developed for (a) members of the Supervisory Boards; (b) members of the Central Executive Boards; (c) secretaries to the Central Executive Boards; (d) members of the University Councils; (e) Deans; (f) members of Faculty Councils; (g) Faculty Directors (i.e. financial managers); (h) members of Education Committees; (i) Directors of Study; and (j) Directors of Research Institutes. The categories (a) to (j) constitute the sample of the 'governors'. Furthermore, questionnaires have been developed for representative samples of (x) academic staff, (y) support staff and (z) students. These constitute the sample of the 'governed'.

The research has yielded a vast amount of interesting findings (see De Boer et al., 2005). Given the interest of the readership of TEAM, the emphasis will be on the results from the survey with respect to participation issues and the conclusions that can be drawn from these empirical findings.

\section{Methodology}

The researchers contacted the thirteen Dutch universities and asked these to provide names and email addresses of persons within each group that is mentioned above. For the categories (a), (b), (c), (d) all 'governors' have been sampled. For the categories (e), (f), (g), (h), (i) and (j) a stratified sampling technique has been used: the researchers selected at random one third of the total number of faculties of Dutch universities and asked the universities to gather names and e- 
mail addresses of governors in the six categories for the selected faculties ${ }^{1}$. The precise number of persons per group could differ from university to university, given the different institutional and governance structures. E.g. the number of faculties per university and the size of the University Councils determined largely the total number of addressees per university. For the category 'governed', the researchers asked the universities to provide at random 90 names and e-mail addresses of academics (stratified according to position: from professor to $\mathrm{PhD}$ student), 50 names and addresses of support staff and 100 names and addresses of students.

In terms of contents of the questionnaires, the researchers covered all five objectives of the new governance structures. A basic set of questions could be used for all groups within the category of 'governors', for a number of groups specifications were needed. The questionnaires for the 'governed' also had many questions in common. The questionnaires of the two categories - the 'governed' and the 'governors' -, however, differed considerably from each other. The main reason for this is clear: the positions, knowledge and experiences of the two categories are rather different. 'Governors' can be asked more technical and detailed questions about the governance and management structure, whilst such knowledge is not expected to be available at academics, non-academics and students that are not (or hardly) involved in university decision-making.

For the categories (a) and (b) the researchers developed paper questionnaires, for the other categories web-based questionnaires were developed. Both questionnaires were launched in January 2005; the database was closed in March 2005.

\section{Response}

In total 4,709 questionnaires have been sent, but it turned out that a number of those addressed after the fact - could not be seen as belonging to the sample: address failure, addressee did not belong to the envisaged category, etc. After data cleaning the sample consisted of 4,426 persons; 1,533 'governors' and 3,044 'governed'. The overall response rate for the governors was $41 \%$, but varied across the groups: ranging from a response rate of $31 \%$ of members of the Education Committee to $88 \%$ of secretaries to the Central Executive Board. The overall response rate for the 'governed' was $26 \%$, ranging from $31 \%$ for both academic and support staff to $19 \%$ for the students. A further analysis of the response and non-response showed that the (characteristics of the) respondents were mirroring the sample expectations.

\section{General judgement on the governance structure}

The general feelings of the respondents regarding the new governance structure can best generally - be captured by presenting their marks (on a scale form 1 ('extremely poor') to 10 ('excellent')). The respondents on average gave a pass ( $\mathrm{m}=6.38, \mathrm{~N}=1277)$. About $80 \%$ of all respondents gave a pass, and one out of five judged the governance structure to be failing (i.e. a mark below 5.5). There are minor differences between the universities. The difference between 'governors' $(\mathrm{m}=6.64, \mathrm{~N}=591)$ and 'governed' $(\mathrm{m}=6.16, \mathrm{~N}=686)$ is significant. Within the category of 'governors', particularly members of the Supervisory Council, the Central Executive Board and Deans were more positive than other 'governors' (such as the members of the representative councils). Within the category of the 'governed', academics score significantly

\footnotetext{
${ }^{1}$ There were some additional sampling requirements, such as a cap to some of the categories, e.g. maximum 10 Directors of Research Institutes and members of Education Committee of maximum three Bachelor Programmes of the faculty.
} 
lower $(\mathrm{m}=5.92, \mathrm{~N}=299)$ than support staff $(\mathrm{m}=6.27, \mathrm{~N}=171)$ and students $(\mathrm{m}=6.40, \mathrm{~N}=216)$. The research does not explain the relatively negative views of the academics. That is, background characteristics such as age, position and institution do not reveal significant differences in the academics' judgements. The researchers suggest that other factors related to the present circumstances academics are confronted with explain their views. The most likely explanation in this respect might well be the serious work loads of present-day academics. In fact, it may in such cases be not a general negative view on the governance structure as such, but a more general discontent with their position.

\section{'Full' participation in Dutch universities}

It is clear that there are many different views on what 'organisational participation' is or should be. It is beyond the scope of this article to theoretically decompose this concept. Here we take a more pragmatic stand. The MUB Act has created several options for the university community to raise its voice in one way or another. The representative councils form one option for the community to participate in the university's policy-making. Another formal way to have a say in this policy-making is though the membership of committees (such as the Education Committee). And of course 'informal interaction' is yet another way of being engaged. Central in our contribution are issues that are related to the representative councils - e.g. their role, their effectiveness - and the possibilities the staff and students (the 'governed') perceive to exert influence (through being represented or in a different way).

In terms of formal authorities the representative councils had to step back considerably with the introduction of the new governance structure. From co-decision-making their role turned into mainly advising the Central Executive Board (at the central level) or the dean (at the faculty level). According to the view of the government this new position of the representative councils should certainly not imply that they would not be taken seriously, but is should not be a surprise that since the introduction of the MUB Act in 1997 opinions differed on this issue.

Therefore, the first question raised concerned the meaning of 'full' participation in the presentday university: what should it be and what is it? Respondents were asked whether they thought full participation meant in practice (a) thinking along with the decision-makers (b), thinking along and talking with the decision-makers or (c) thinking along, talking with and deciding with the decision-makers. This division in forms of participation form a continuum from limited to more serious participation. A second question was which of the three options they would prefer. The outcomes of these two questions - posed to all groups - are presented in table 1.

Hardly any respondent thought full participation should be limited to thinking along and hardly any respondent thought that such a situation was practised. Executives (members of the Central Executive Board, Supervisory Council and Deans) held quite often the opinion that participation of the representatives councils should be "thinking along and talking with decision-makers", but that in their eyes in practice there quite often were situations of "thinking along, talking with and deciding with the decision-makers". The members of the councils significantly disagreed with the 'governors'. According to their view full participation should imply "thinking along, talking with and deciding with the decision-makers", whereas in practice it turns out to be "thinking along and talking with decision-makers". 
Table 1: The preferred and perceived meaning of full participation (in \%, by actor)

\begin{tabular}{|c|c|c|c|c|c|c|c|c|c|c|c|}
\hline & $\mathrm{CvB}$ & RvT & CMR & $\mathrm{DEC}$ & $\mathrm{BO}$ & OLC & WD & FMR & WP & ST & OBP \\
\hline \multicolumn{12}{|l|}{$\begin{array}{l}\text { Full participation } \\
\text { should imply: }\end{array}$} \\
\hline Don't know/ / no opinion & - & - & - & - & - & - & - & - & 5 & 6 & 4 \\
\hline Thinking along & 0 & 0 & 1 & 0 & 3 & 1 & 0 & 0 & 3 & 2 & 3 \\
\hline .... and talking with & 83 & 69 & 23 & 75 & 51 & 18 & 36 & 17 & 19 & 20 & 21 \\
\hline .... and deciding with & 17 & 31 & 77 & 25 & 46 & 82 & 64 & 83 & 73 & 72 & 72 \\
\hline $\mathrm{N}(=100 \%)$ & 23 & 45 & 144 & 12 & 35 & 162 & 22 & 134 & 321 & 227 & 180 \\
\hline \multicolumn{12}{|l|}{$\begin{array}{l}\text { Full participation } \\
\text { actually is: }\end{array}$} \\
\hline Don't know/ / no opinion & - & - & - & - & - & - & - & - & 33 & 45 & 24 \\
\hline Thinking along & 0 & 0 & 18 & 0 & 23 & 23 & 23 & 12 & 13 & 7 & 12 \\
\hline .... and talking with & 52 & 54 & 64 & 75 & 60 & 69 & 68 & 59 & 44 & 39 & 55 \\
\hline .... and deciding with & 48 & 46 & 18 & 25 & 17 & 8 & 9 & 29 & 9 & 10 & 10 \\
\hline $\mathrm{N}(=100 \%)$ & 23 & 41 & 143 & 12 & 35 & 156 & 22 & 132 & 322 & 227 & 179 \\
\hline
\end{tabular}

Note: $\mathrm{CvB}=$ Central Executive Board, RvT $=$ Supervisory Board, $\mathrm{CMR}=$ University Council, DEC $=$ Dean, $\mathrm{BO}=\mathrm{Director}$ of Studies, OLC $=$ Education Committee, WD=Director of Research Institute, FMR=Faculty Council, WP=academics, OBP=support staff, $\mathrm{ST}=$ students

Another, related question concerned the effectiveness of the representative councils. They may have been stripped from their main powers, but this does not automatically imply that they are toothless. Have representative councils sufficient influence on policy development? Can they control the implementation of the main university policies? The views on the influence of representative councils on policy development differ considerable among and within the groups of the category 'governors'. On average, more than half of the 'governors' (54\%) thinks that the influence of the representative bodies is sufficient, which means that almost the other half has a different opinion.

With respect to the second question - have councils sufficient possibilities to control the major policy lines of the university - the outcomes are the following ${ }^{2}$. About three quarters of the members of representative councils ( $71 \%$ at the central level, $78 \%$ at the faculty level) are of the opinion that they are able to control the main policy lines. Executives and members of representative councils differ very much in pointing at reasons for an insufficient influence on policy development. Governors tend to refer to a lack of skills and knowledge of council members and a lack of consensus among members (divided opinions in the council hinder its effectiveness). In turn, council members mention that a lack of sound information, a lack of timely information and lack of time particularly contribute to an insufficient influence. These outcomes show that though the representative councils had to make sacrifices in their authorities, they still have - according to the views of a substantial number of those directly

\footnotetext{
${ }^{2}$ Only the members of the representative councils have been asked this second question with respect to the effectiveness of these councils (at both the central and the faculty level).
} 
involved in the art of governing - some influence on the policy-making of their universities. This is, however, not spotted by everyone within the university.

Many of the 'governed', for instance, are not aware of what representative councils do; $75 \%$ does not know about the work and performances of the central-level councils and $60 \%$ does not know this about the faculty-level councils. Nevertheless, a majority of those who say to know what the councils do think that their interests are well presented by those councils $(60 \%$ at the central level, $65 \%$ at the faculty level). There is, in general, a troublesome relationship between the representatives and the represented. It is hard for council members to get their message across, which is probably partly due to a lack of interest from the side of the represented.

More than half (53\%) of the governed - particularly students - are not interested (at all) in governance issues at the faculty level. Only $12 \%$ says that they are interested in governance and policy issues at their faculty. The large majority indicates not being available for a seat in representative councils (this percentage - by the way - does not differ much from the 1970s and 1990s). "It takes too much time" is mentioned most (57\%) followed by "a lack of interest in council activities" (34\%) as their motive not to take up such a position. This partly explains the difficulty finding (suitable) persons for the councils. The fact that the work and achievements of the councils is often unknown (33\%) in addition explains the low interest in a position in a representative council. Another indicator of low commitment regarding governance issues forms the turn-out rates of elections. For example, roughly $30 \%$ of the academic community (staff and students) has voted during the last elections for the university council.

As mentioned the councils provide one way to exert influence on university and faculty policymaking. There are other options as well. A majority of academics and students thinks that they have sufficient influence on education. Table 2 gives an overview of the views of academics and students. The differences between these two groups are not significant. With respect to the content of education as well as with respect to the educational process of majority of academics and students hold the opinion that they can influence respectively content and process. At the same time we can see that about a third (contents) and $43 \%$ (process) has the opinions that their influence is insufficient.

Table 2: The perceived influence on the educational contents and process (in \%)

\begin{tabular}{|c|c|c|c|}
\hline The influence on the contents of education is in general: & total & WP & STUD \\
\hline Totally insufficient & 5 & 5 & 5 \\
\hline Insufficient & 27 & 17 & 42 \\
\hline Sufficient & 56 & 59 & 52 \\
\hline Fully sufficient & 12 & 19 & 3 \\
\hline $\mathrm{N}(=100)$ & 481 & 279 & 202 \\
\hline
\end{tabular}

The influence on the educational process is in general:

\begin{tabular}{|c|c|c|c|}
\hline Totally insufficient & 8 & 9 & 7 \\
\hline Insufficient & 35 & 35 & 36 \\
\hline Sufficient & 51 & 50 & 52 \\
\hline Fully sufficient & 6 & 6 & 5 \\
\hline $\mathrm{N}(=100)$ & 465 & 270 & 195 \\
\hline
\end{tabular}


The interpretation of this outcome is one of degree (or taste). To put is slightly different, one may say that the glass is both half full and half empty. This picture is confirmed when asked about the possibilities to exert influence if there is a felt need of doing this (table 3). About half of the respondents believes that this is the case, whereas a third does not see sufficient opportunities to 'raise its voice' when necessary. With respect to the last question we see a difference between students and academics: students are more positive than academics and support staff. What is also eye-catching in table 3 is that some $15 \%-22 \%$ of the respondents are ignorant with respect to their opportunities to have an impact on policy-making. This may tell us something about the unfamiliarity with or indifference in governance matters of some of the staff and students, but it could also signal the lack of transparency of the governance structure.

Tabel 3: Views on influence to contribute to decision-making (in \%)

\begin{tabular}{lrrrr}
\hline $\begin{array}{l}\text { There are for me }- \text { if I wanted so }- \text { sufficient opportunities to contribute to } \\
\text { decision-making }\end{array}$ & total & WP & STUD & OBP \\
\hline Don't know & 18 & 15 & 20 & 22 \\
Strongly disagree & 6 & 10 & 2 & 3 \\
Disagree & 28 & 32 & 16 & 35 \\
Agree & 44 & 40 & 55 & 39 \\
Strongly agree & 4 & 3 & 8 & 1 \\
& & & & \\
$\mathrm{~N}(=100 \%)$ & 725 & 322 & 222 & 181 \\
\hline
\end{tabular}

Note: $\mathrm{WP}=$ academics, $\mathrm{OBP}=$ support staff, $\mathrm{ST}=$ students

The findings regarding 'full participation' do not immediately answer our question to what extent this objective of the MUB Act has been reached eight years after its implementation. This is to some extent a matter of degree, most likely depending on where one's position is in- or outside the university, as well as unclearness about its precise meaning. The data show that the executives and council members have different preferences and different perceptions of this concept of full participation. The executives (members of central executive boards, supervisory boards and deans) would prefer full participation in which the representative councils are "talking with" the executives and they think the actual situation comes close to "deciding with". Contrary members of the representative councils (at central and faculty level) would prefer a structure in which the councils "decide with" the executives, whereas they experience the present situation as "talking with". Despite these opposite views, at least half of the members of representative councils are of the opinion that they are able to generally control the policy developments. As advisory councils ${ }^{3}$ they are certainly not purely decorative. However, many staff and students are not aware of what representative councils do and they are not interested in governance issues. At the same time, and somewhat odd, many staff and students are of the opinion that their interests are well represented, although students are a bit more positive than staff.

There are, besides through the representative councils, other ways to influence the university policies. Half of the students and staff see opportunities to raise their voice if they want to. Informal contacts and personal networks are extensively used, as the follow-up actions of universities as a consequence of the outcomes of the universities' self evaluations from 2001 indicate and as the 2005 national evaluations study has confirmed. With a few exceptions, the

\footnotetext{
${ }^{3}$ Again, the councils have more authorities than just advisory ones. Therefore we would like to speak of "heavily equipped" advisory bodies as long as one takes into account that "decisive" powers such as the budget right has disappeared.
} 
interaction pattern among the governors and among governors and governed is typified as 'good', 'informal' and 'relaxed'.

To conclude we would argue on the basis of these results that the participation of the university community is not as bad as commonly expected, while at the same time serious worries remain. We assume that the (mixed) perceptions towards participation matters is coloured by the perceptions of the performances of the governing structure. In the next section we spend a few words on this issue.

\section{Effective and efficient decision-making}

Here we asked staff and students whether they thought that their governing structure could be qualified as being decisive. Decisiveness has been defined as the potential of the governing bodies as a whole (i.e. the councils) to solve wicked problems in relatively short periods of time. This decisiveness is regarded as an indicator of the performance of the governing structure as such. More than $60 \%$ of the 'governed' thinks that the governing bodies have not been acting vigorously (table 4). Just over a third of the academics have been 'impressed' by the governing performances. In table 5 we see that the 'governors' have a slightly different view. They are more positive about the decisiveness of the governing bodies. Some of the Directors of Study are disappointed (26\% thinks that the decisiveness is (very) poor), whilst the other respondents are, generally speaking, rather satisfied with the vigorousness of the governing bodies. This outcome is supported by a more concrete question on the same matter. All groups in the category of the 'governors' have been asked if the university has been able to implement successfully major reforms (such as the Bachelor Master structure) over the last years. A majority of the respondents agreed with this statement. Especially the executives were convinced that the university has successfully carried through such reforms. Members of the representative councils, the members of the Education Committees and the Scientific Directors of research institutes were on average less positive, in the sense that a substantial minority did not perceive the implementation of reforms as successful.

When we compare the outcomes in table 4 and table 5 , it is clear that the position that one takes influences one's perception. Those actively involved in university decision-making processes (the governors) have on average different perceptions than those not actively engaged (the governed) in these processes. Being unfamiliar with or lacking the information (e.g. about the nature of the problems) apparently easily leads to a perception of non-performing. 'Being on the other side', those directly involved may explicitly face the complexity and obstinacy of some of the problems and consequently are more tolerant and understandingly in their view.

Table 4: The decisiveness of governing bodies according to the governed (in \%)

\begin{tabular}{lcccc}
\hline According to your view, how decisive is the governing bodies? & total & WP & STUD & OBP \\
\hline Totally insufficient & 12 & 16 & 5 & 10 \\
Insufficiently & 50 & 48 & 51 & 52 \\
Sufficiently & 35 & 32 & 41 & 36 \\
Fully sufficient & 3 & 4 & 2 & 2 \\
& & & & 152 \\
\hline $\mathrm{N}(=100 \%)$ & 584 & 271 & 161 \\
\hline
\end{tabular}

Note: $\mathrm{WP}=$ academics, $\mathrm{OBP}=$ support staff, $\mathrm{ST}=$ students 
Table 5: The decisiveness of governing bodies according to the governors (in \%)

\begin{tabular}{|c|c|c|c|c|c|c|c|c|c|c|c|}
\hline & \multicolumn{5}{|c|}{ UNIVERSITY } & \multicolumn{6}{|c|}{ FACULTY } \\
\hline $\begin{array}{l}\text { According to your view, how } \\
\text { decisive are the governing bodies } \\
\text { of your university/faculty? }\end{array}$ & CvB & RvT & CMR & SEC & DEC & DEC & DB & BO & OLC & WD & FMR \\
\hline Absolutely not & 9 & 2 & 3 & & & & & 6 & 4 & & 1 \\
\hline Hardly & 9 & 4 & 13 & & 8 & 8 & & 20 & 12 & 13 & 7 \\
\hline To some extent & 35 & 22 & 38 & 17 & 17 & & 31 & 23 & 42 & 30 & 37 \\
\hline Considerably & 43 & 35 & 43 & 67 & 67 & 58 & 69 & 43 & 38 & 48 & 50 \\
\hline Strongly & 4 & 35 & 3 & 17 & 8 & 33 & & 9 & 4 & 9 & 5 \\
\hline $\mathrm{N}(=100 \%)$ & 23 & 44 & 142 & 6 & 12 & 12 & 13 & 35 & 161 & 23 & 135 \\
\hline
\end{tabular}

Note: $\mathrm{CvB}=$ Executive Board, RvT=Supervisory Council, $\mathrm{CMR}=$ central-level representative council, $\mathrm{SEC}=$ Secretary to the Executive Board, DEC=Dean, DB=Faculty Director, $\mathrm{BO}=$ Director of Studies, OLC=Education Committee, WD=Director of Research Institute, FMR=faculty-level representative council

Quite a number of respondents are of the opinion that the decisiveness on paper has been larger than the actual decisiveness. There are, however, substantial differences in views with respect to this statement. Most of the executives reject the statement (e.g. 52\% of members of the Central Executive Board and $61 \%$ of the members of the Supervisory Board disagree), whereas twothirds of members of the central representative councils agree. Also a majority of the Scientific Directors, the members of the Education Committee and the Faculty Councils members agree with the statement that the 'thirst for action' has been bigger than the actual decisiveness.

Of course there are more indicators with respect to the effectiveness of the governing structure. For example the capacity to develop serious strategic plans. In the past universities have regularly been 'accused' of not being able to design university-wide policies, since, to mention just one reason, the authorities were dispersed across the organisation. Is a university in which the executive core is formally strengthened able to draw up and implement such strategic documents? The majority of the respondents (in the category of the 'governors') think that the university has been able to carry out a transparent and coherent strategic policy, although the members of representative councils ( $49 \%$ disagree), the members of education committees (53\% disagree) and particularly the research directors (65\% disagree) are less positive.

Whether the governing efforts have been worthwhile - compared to the energy and time invested - is judged rather differently by groups of respondents. It is clear that the executives hold timeconsuming positions, but may be less obvious also quite a few members of representative councils and committees spent many hours on governing matters. Do such costs balance the benefits (in one form or another)? Members of the Supervisory Board (78\% agree) and Education Committee (70\% agree) are more positive than members of the central representative council ( $75 \%$ disagree) and Directors of Study (69\% disagree). The outcomes regarding the deanship regularly seen as a tough and time-consuming position- are divided: $50 \%$ believes the costs are too high in relation to the benefits and the same proportion has the opposite opinion.

\section{Reflection}

The university governance structure is - according to a majority of the respondents - effective at a satisfactory level. Certainly, there are problematic issues and differences in perspectives, but the national evaluation study has indicated that a situation of an almighty central executive accompanied by very powerful deans managing university or faculty (following the ideas of managerialism) has not been encountered. The general fear with the introduction of the MUB Act in 1997 was, at least in certain settings, the 'decline of collegialism' or the 'death of participatory 
decision-making' through non-approachable executives with limited knowledge and commitment as regards the actual teaching and research processes. Such a picture is absolutely wrong. Just as the MUB's illustrious predecessor could (and should) be questioned in terms of its 'democratic content', the MUB should be carefully assessed in terms of its 'executive content'. It is misleading to suggest time and again that strong management is all wrong. There is no doubt that the Dutch executives have gained a more prominent role in university decision-making, but as the national evaluation study shows this does not mean that 'others' are excluded from the game nor that the 'others' are automatically dissatisfied with the 'professionalised' governing structure of the university.

At the same time it seems that the Dutch 'governors' are in an intermediate position towards the continuous professionalisation of university governance. Some faculties are (still) run by parttime deans that prefer to be academics, whilst at some other faculties deans are full-time committed to professional management. Also the participation and involvement of the members of the university community in policy-making processes require further attention. The position and role of the representative councils, as one form of formal participation of the university community, has improved, albeit that the governance puzzle in terms of full participation is certainly not fully solved. Even if this would be the case, there will continue to be a tension between the wishes and needs of the university community and the governance reality as well as between the wishes and needs of the executives and the academic reality. But professional organisations must be able to cope with such situations.

\section{References}

Amaral, A., G.A. Jones and B. Karseth (eds. 2002) Governing higher education: National perspectives on institutional governance. Dordrecht: Kluwer.

Van den Berg, J.J., H. van Bergen and R. Schouten (2001) De bezinning op de MUB - een tussenstand. Den Haag: B\&A groep.

De Boer, H., and L. Goedegebuure (2001) On limitations and consequences of change: Dutch university governance in transition, Tertiary Education and Management 7: 163-180.

De Boer, H. and L. Goedegebuure (2002) Een evaluatie waar niemand op zat te wachten, TH\&MA 9(2), 46-48.

De Boer, H., L. Goedegebuure and J. Huisman, with E. Beerkens and J. Deen (2005) Gezonde spanning. Beleidsevaluatie van de MUB. Beleidsgerichte studies Hoger onderwijs en Wetenschappelijk onderzoek 114. Den Haag: Ministerie van OCW.

Clarke, J., and J. Newman (1997) The managerial state. London: Sage.

Committee Datema (1998), De kanteling van het universitaire bestuur. Zoetermeer: MOCenW.

LSVb (2002) MUB - Een échte evaluatie. Utrecht, Landelijke Studentenvakbond (LSVb) en Landelijk Overleg Fracties (LOF): 64.

Neave, G., and F.A. van Vught (1991), Conclusion. In: G. Neave and F.A. van Vught (eds.), Prometheus bound. The changing relationship between government and higher education in Western Europe. Oxford: Pergamon Press, 264-319.

Pollitt, C. (1990), Managerialism and the public services. Cuts and cultural change in the 1990s. Oxford: Blackwell.

Pollitt, C., and G. Bouckaert (eds 2000), Public management reform. A comparative analysis. Oxford: Oxford University Press. 